\title{
INKRUHEDAMASEDA (Inovasi Krupuk Herbal Daun Manggis Sebagai Antioksidan untuk Mewujudkan Ekonomi Negri)
}

\author{
Riski Kurniawan ${ }^{1 *}$ \\ ${ }^{1}$ SMAN 1 Labuan Maringgai \\ *Corresponding author: riskibertani7777@gmail.com
}

\begin{abstract}
Abstrak
Tanaman manggis adalah salah satu tanaman yang banyak tumbuh di sekitar tempat tinggal kami. Sudah banyak masyarakat yang tau akan khasiat dari tanaman ini dari kulit buah nya sampai dengan daunnya, yaitu sebagai antioksidan dan vitamin c yang bermanfaat bagi kesehatan tubuh, diantaranya sebagai obat pencegah kanker, sebagai daya tahan tubuh, darah tinggi, obat diare, penangkal radikal bebas, pencegah panas dalam dan masih banyak lagi yang lainnya. Selama ini masyakarat dalam mengkonsumsi kulit buah dan daun manggis ini hanya di rebus dan di minum air sarinya. Dari sini muncul lah ide kami untuk menginovasikan daun manggis menjadi makanan yang bisa disenangi oleh semua kalangan, serta memiliki nilai gizi tinggi dan bermanfaat bagi kesehatan. Tujuan dari penelitian kami yaitu untuk mengetahui kandungan daun manggis dan cara pengolahan daun manggis menjadi krupuk agar mejadi produk alternatif yang bergizi tinggi supaya disenangi masyarakat dan menjadi peluang usaha.
\end{abstract}

Kata kunci: Antioksidan, Daun manggis, Krupuk, Herbal, Bergizi

\begin{abstract}
The mangosteen plant is one of the most common plants in our neighborhood. There are many people who know the benefits of this plant from the skin of the fruit to the leaves, namely as an antioxidant and vitamin $C$ which is beneficial for the health of the body, including as a cancer prevention drug, as a body resistance, high blood pressure, diarrhea medicine, antidote to free radicals. , internal heat prevention and many others. So far, people who consume mangosteen rind and leaves are only boiled and drinking the juice. From this, our idea emerged to innovate mangosteen leaves into food that can be enjoyed by all groups, and has high nutritional value and is beneficial for health. The purpose of our research is to determine the content of mangosteen leaves and how to process mangosteen leaves into crackers in order to become a highly nutritious alternative product so that the community likes it and becomes a business opportunity.
\end{abstract}

Keywords: Antioxidants, Mangosteen Leaves, Krupuk, Herbal, Nutritious 
Prosiding Seminar Nasional Pembangunan dan Pendidikan Vokasi Pertanian

Politeknik Pembangunan Pertanian Manokwari, 14 November 2020

e ISSN : 2774-1982

\section{PENDAHULUAN}

Krupuk adalah salah satu produk olahan tradisional yang di gemari oleh masyarakat Indonesia. Makanan tersebut di kenal baik di segala usia maupun tingkat soaial masyarakat, mudah di peroleh dan di jual dengan harga murah baik dalam kemasan yang sudah di goring maupun dalam keadaan mentah. Krupuk berstekstur renyah dan garing yang dapat di konsumsi sebagai variasi dalam lauk pauk (Koswara, 2009).

Berbagai jenis krupuk banyak tersedia di masyarakat mulai dari krupuk yang hanya berbahan dasar tepung tapioka hingga krupuk yang diberi campuran ikan atau udang. Berdasarkan daerah penghasil dikenal krupuk Palembang, sidoharjo, Surabaya (Koswara, 2009). Menurut penelitian irfansyah (2001), tepung ubi jalar putih dan jingga dapat di gunakan pada pembuatan krupuk ikan tenggiri. Kualiatas krupuk yang paling baik adalah menggunakan tepung ubi jalar putih penambahan maksimal ubi jalar dalam adonan krupuk adalah sebesar $40 \%$ atau formulasi adonan unruk tepung tapioka:tepung ubi jalar:tepung terigu sebesar 50:40:10.

Selain itu juga terdapat krupuk dengan beragam variasi bahan mulai dari tepung tapioka, tepung terigu, tepung ubi jalar dan lain sebagainya. Untuk menambah variasi krupuk yang beredar di kalangan masyarakat maka peneliti memanfaatkan libah tanaman manggis sebagai bahan tambahan pembuatan krupuk.

Tanaman manggis merupakan salah satu tanaman yang banyak tumbuh di sekitar tempat tinggal kami. Sudah banyak masyarakat yang tau akan khasiat dari tanaman ini dari kulit buah nya sampai dengan daunnya, Selama ini masyakarat dalam mengkonsumsi kulit buah dan daun manggis ini hanya di rebus dan di minum air sarinya. Dari sini muncul lah ide kami untuk menginovasikan daun manggis menjadi makanan yang bisa disenangi oleh semua kalangan, serta memiliki nilai gizi tinggi dan bermanfaat bagi kesehatan.

Daun manggis adalah salah satu daun yang memiliki warna hijau. Tidak semua masyarakat tau cara mengolah daun manggis. Namun sebenarnya daun manggis sangat baik untuk kesehatan tubuh kita. Selain itu daun manggis mengandung antioksidan dan vitamin c yang bermanfaat bagi kesehatan tubuh. Beberapa manfaat dari daun manggis ini adalah: mencegah kanker, sebagai daya tahan tubuh, darah tinggi, obat penyakit diare, penangkal radikal bebas dan meredakan panas dalam.

Kerupuk herbal daun manggis masih sangat jarang kita temui di Indonesia. Sajian kerupuk herbal daun manggis ini dijadikan untuk camilan yang bergizi dan bermanaat bagi kesehatan. Peluang bisnis kerupuk daun manggis masih sangat lebar. Dengan menjalankan 
Prosiding Seminar Nasional Pembangunan dan Pendidikan Vokasi Pertanian Politeknik Pembangunan Pertanian Manokwari, 14 November 2020

e ISSN : 2774-1982

kegiatan usaha kerupuk herbal daun manggis bisa mendatangkan keuntungan dan menciptakan peluang usaha serta melatih jiwa kewirausahaan dikalangan pelajar.

\section{METODE}

Penelitian ini di lakukan di SMAN 1 Labuhan Maringgai waktu penelitian di lakukan pada 10 september 2019 terhadap siswa kelas XI IPA2. Penelitian ini bertujuan untuk mengetahui antara dua variabel yaitu uji coba krupuk daun manggis dengan metode pembuatan krupuk tanpa pembuangan tulang daun manggis (x) dan pembuangan tulang daun manggis $(\mathrm{y})$.

\section{HASIL DAN PEMBAHASAN}

Hasil penelitian dan pembahasan dalam jurnal ini berupa mengetahui perbandingan antara variabel (x) dan (y), menganalisis data keuntungan yang di peroleh dalam pemasaran produk daun manggis dan mengetahu manfaat dari kandungan daun manggis.

Tabel 1. Analisis data variabel (x)

\begin{tabular}{|c|c|c|}
\hline Siswa & Rasa Gurih & Rasa Pahit \\
\hline $\mathrm{a}$ & & Pahit \\
\hline b & & Pahit \\
\hline $\mathrm{c}$ & & Pahit \\
\hline $\mathrm{d}$ & & Pahit \\
\hline e & Gurih & \\
\hline$f$ & & Pahit \\
\hline g & & Pahit \\
\hline $\mathrm{h}$ & Gurih & \\
\hline $\mathrm{i}$ & & Pahit \\
\hline $\mathrm{j}$ & & Pahit \\
\hline Jumlah Total & 2 Orang & 8 Orang \\
\hline
\end{tabular}

Sumber: Data primer, 2019

Berdasarkan Tabel 1 yang di peroleh pada variabel (x) dalam peroses pembuatan krupuk herbal daun manggis tanpa pemberian tulang daun manggis yang di ujikan terhadap 10 siswa di dapat hasil 8 orang merasakan rasah pahit dan 2 orang merasakan gurih. 
Tabel 2. Analisisi data variabel (y)

\begin{tabular}{lll}
\hline \multicolumn{1}{c}{ Siswa } & Rasa Gurih & Rasa Pahit \\
\hline $\mathrm{a}$ & Gurih & Gurih \\
$\mathrm{b}$ & Gurih & \\
$\mathrm{c}$ & Gurih & \\
$\mathrm{d}$ & Gurih & \\
$\mathrm{e}$ & Gurih \\
$\mathrm{f}$ & Gurih \\
$\mathrm{g}$ & Gurih & \\
$\mathrm{h}$ & Gurih & \\
$\mathrm{i}$ & Gurih & - \\
$\mathrm{j}$ & 10 Orang
\end{tabular}

Sumber: Data primer, 2019

Berdasarkan Tabel 2 yang di peroleh pada variabel (y) dalam peroses pembuatan krupuk herbal daun manggis tanpa menggunakan tulang daun di peroleh hasil 10 siswa merasakan rasa gurih tanpa merasakan rasa lidah yang pahit.

Tabel 3. Analisisi data keuangan

\begin{tabular}{|c|c|}
\hline Biaya Variabel & Jumlah Harga (Rp) \\
\hline Tepung Tapioka $1000 \mathrm{~g}$ & $10.000,-$ \\
\hline Tepung Beras $100 \mathrm{~g}$ & $3.000,-$ \\
\hline Minyak Goreng $500 \mathrm{ml}$ & $6.000,-$ \\
\hline Garam & $1.000,-$ \\
\hline Gula & $1.000,-$ \\
\hline Bawang Putih 10 Siung & $2.000,-$ \\
\hline Gas & $4.000,-$ \\
\hline Total Vaiabel & 27.000,- \\
\hline
\end{tabular}

Pada pembuatan krupuk daun manggis dengan menganalisis data keuangan keuangan, keuntungan yang di peroleh dari jumlah produksi makanan di kalikan dengan

$\begin{array}{ll}\text { Harga penjualan } & : \text { : } 62 \text { bungkus x Rp.1.000 = Rp.62.000 } \\ \text { Modal } & : \text { Rp. } 27.000,- \\ \text { Laba } & \text { : Rp.62.000 - Rp. } 27.000=\text { Rp.35.000 }\end{array}$


Prosiding Seminar Nasional Pembangunan dan Pendidikan Vokasi Pertanian Politeknik Pembangunan Pertanian Manokwari, 14 November 2020

e ISSN : 2774-1982

\section{Saponin}

Beberapa hasil penelitian yang telah kami lakukan dalam pengujian kandungan saponin dari Gambar 1 terlihat adanya aktifitas kandungan saponin.
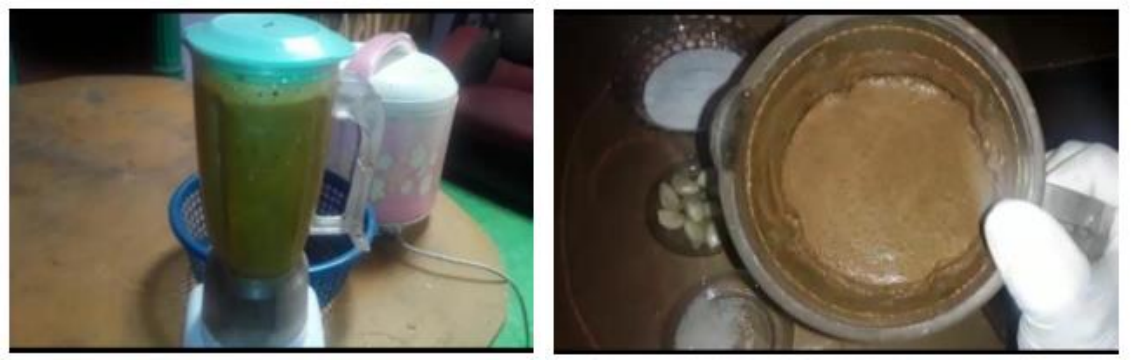

Gambar 1. Proses blender

Saponin merupakan senyawa dalam bentuk glikosida yang tersebar luas pada tumbuhan tingkat tinggi. Samponin membentuk larutan koloidal dalam air dan membentuk busa yang mantap jika di kocok dan tidak hilang dalam penambahan asam (Herbrone, 1996). Samponin merupakan golongan senyawa alam yang rumit, yang mempunyai masa dan molekul besar, dengan kegunaan luas (Burger et al., 1998). Samponin di beri nama demikian karna sifatnya menyerupai "Sapo" berarti sabun. Samponin adalah senyawa akif permukaan yang kuat dan menibulkan busa bila di kocok dengan air beberapa samponin berkerja sebagai antimikroba. Dikenal juga jenis samponin yaitu glikosida triterpenoid dan glikosida struktur steroid tertentu yang mempunyai rantai spirotekal. Kedua samponin ini larut dalam air dan etanol, tetapi tidak larut dalam eter. Aglikonya disebut sapogenin, diperoleh dengan hidrolisis dalam suasana asam atau hidrolisis memakai enzim (Robinson, 1995).
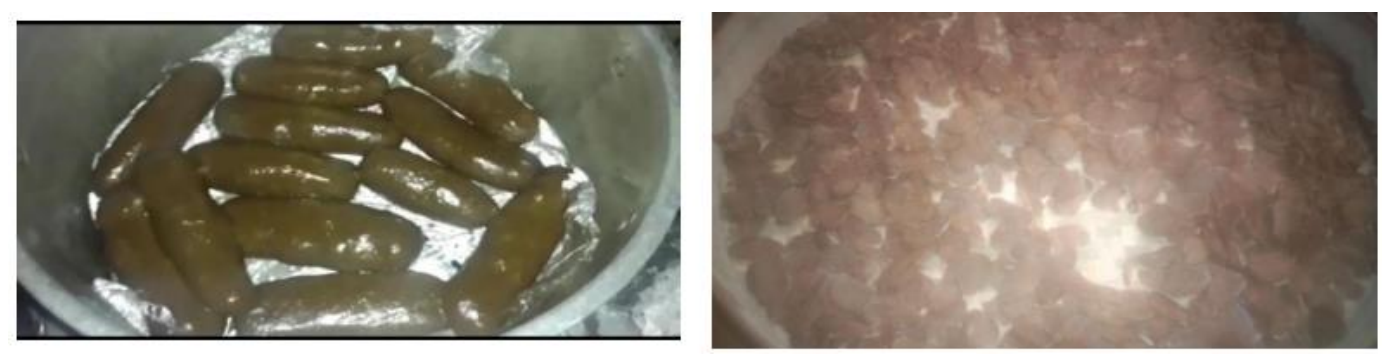

Gambar 2. Krupuk daun manggis

\section{Kandungan Kimia Daun Manggis}

Manggis merupakan tanaman buah yang berasal dari hutan tropis yang teduh di kawasan asia tenggara, yaitu hutan belantara Malaysia atau Indonesia. Di Indonesia manggis di sebut dengan berbagai macam nama lokal seperti manggu (jawa barat),manggis 
Prosiding Seminar Nasional Pembangunan dan Pendidikan Vokasi Pertanian

Politeknik Pembangunan Pertanian Manokwari, 14 November 2020

e ISSN : 2774-1982

(jawa), manggusto (sulawesi utara), maangustang (Maluku) dan manggih (sumatra barat) (Prihatman, 2000).

Manggis merupakan tanaman yang seluruh bagian tanamannya dapat di manfaatkan mulai dari daging, buah, kulit, daun, batang dan akar manggis mempunyai kandungan senyawa turunan xanton yang mempunyai antofita biologi, sebagai antibakteri, antimikroba, antiinflamasi, antioksidan, dan dapat menghambat pertumbuhan sel kanker usus (Putra, 2010 ).

Estrak dan fraksi daun manggis memiliki aktifitas anti bakteri terhadap staphylouosusaures dengan diameter zona hambat control positif cipofloacin $25 \mathrm{~mm}$. hasilhasil uji kadar hambat minimum KHM dan kadar bahan minimum KBM pada kosentrasi 12.5\%. Estrak daun manggis memiliki kandungan senyawa flavonoid, istroid, dan samponin (Turahman, 2018). Etanol daun Manggis mempunyai kandungan senyawa triteponoit, flavonoid, tanin dan samponin yang dapat membeikan efek farmologis (jurnal ilmiah farmasi-UNSRAT manado, 2018).

Banyak penelitian yang di lakukan terhadap kulit dan buah manggis namun bagian daun belum banyak yang di teliti kususnya kandungan senyawa metabolit sekunder dan toksitasnya.ditemukan efek samping dari obat tradiosional (Hendrawati, 2008). Dari hasil penelitian yang di lakukan ini, perlu di lakukan penelitian yang lebih lanjut mengenai daun manggis karna daun mangis memiliki berbagai senyawa metabolit sekunder yang bermanfaat dan pula bersifat toksiksangat berpotensi sebagai bahan obat anti kanker (jurnal ilmiah manado -USURAT manado, 2018).

\section{Aktivitas Antioksidan}

Antioksidan merupakan senyawa yang dapat menunda atau mencegah terjadinya reaksi oksida radikal bebas dalam oksidasi lipit dalam konsentrasi yang lebih rendah dari substrat yang dapat di oksidasi antioksidan bereaksi dengan radikal bebas sehingga mengurangi kapasitas radikal bebas untuk menimbulkan kerusakan. Dalam bahan pangan, antioksidan banyak terdapat dalam sayur dan buah- buahan seperti jeruk, apel, kol merah, bit, manggis dan sebagainya .antioksidan alamai yang terdapat dalam bahan pangan tersebut Antara lain adalah vitamin C, vitamin E, antosianin klorofil dan senyawa flavonoid antioksidan alami pada umumnya berbentuk cairan pekat dan sensitivf terhadap pemanasan (Deman, 1997).

Radikal bebas adalah molekul yang sangat relative karna memiliki electron tidak berpasangan pada orbital luarnya sehingga dapat bereaksi dengan molekul sel tubuh dengan cara mengikat electron sel tersebut, dan mengakibatkan reaksi berantai yang 
Prosiding Seminar Nasional Pembangunan dan Pendidikan Vokasi Pertanian

Politeknik Pembangunan Pertanian Manokwari, 14 November 2020

e ISSN : 2774-1982

menghasilkan radikal bebas baru (Deman, 1997). Antioksidan bereaksi dengan radikal bebas dengan cara mengurangi konsentrsi oksigen mencegah pembentukan singlet oksigen yang relativf, mencegah inisiasi rantai pertama dengan menangkap radikal primer seperti radikal hidroksil, mengikat katalis ion logam, mendekomposi produk- produk primer radikal menjadi senyawa non-radikal, dan memutus rantai hidroproksida (shahidi, 1997).

Antioksidan berdasarkan mekanisme kerjanya di kelompokan menjadi Shahidi dan Naczk, 1995):

1. Antioksidan Primer yaitu antioksidan yang bereaksi dengan radikal lipit berenergi tinggi untuk menghasikan produk yang memiliki kesetabilan termodinamis lebih baik. Antioksidan golongan fenol seperti isoflavon termasuk dalam antioksidan yang memiliki mekanisme ini.

2. Antioksidan Sekunder yang di kena juga antioksidan pencegah (Preventif Antioxidant) yang dapat memperlambat reaksi inisiasi dengan cara memutus rantai (chain breaking antioxidant) hidroperoksida. Contoh: anioksidan ini yaitu dilaurilthiodipropionate dan asam thiodippropionic. Antioksidan golongan ini adalah antioksidan yang berikatan dengan gugus Thiol.

Xanthone merupakan bagian dari flafonoid yaitu senyawa polifenol. Polifenol teraebar di alam, mekanisme antioksidan senyawa folifenol berdasarkan ata kemampun mendonorkan atom hiydrogen dan kemampuan melekat ion-ion logam, lalu senyawa fenolik menstabilkan radikal secara resonasi, yang tidak mudah berpatisipasi dalam reaksi radikal lain (Muchtadi, 2011).

\section{Manfaat Tumbuhan Manggis}

Manfaat tumbuhan manggis khususnya Xantone adalah:

1. Antioksidan. Dalam proses metabolismnya, terjadi reaksi oksidasi dan redoksi sehingga di hasilkan radikal bebas yang bersifat oksidator dengan oksigen yang relativf. Radikal bebas akan mengoksidasi zat-zat atau senyawa yang bermanfaat bagi tubuh, sehingga jaringan sel-sel tubuh rusak( Paramawati, 2010).

2. Antiviral. Mangostinxanthone yang terkandung dalam kulit manggis menghambat siklus replikasi virus HIV (Vilentink et al., 1998). Penelitian menyimpulkan bahwa kulit manggis menujukan potensi menghambat HIV-1 protease yang mempengaruhi replikasi HIV.

3. Antifungal. Xanthone juga memiliki kemampuan untuk menghambat aktifitas kampang atau jamur. Penyebab penyakit atau fitophatogenik. Beberapa contohnya 
Prosiding Seminar Nasional Pembangunan dan Pendidikan Vokasi Pertanian

Politeknik Pembangunan Pertanian Manokwari, 14 November 2020

e ISSN : 2774-1982

adalah Fusariumoxysporum V, Altemariatenuis, dan Dreschleraoryzae (Cocheliobolusmiyabeanu) (Paramawati, 2010).

4. Antibakteri. Beberapa penelitian tentang manfaat senyawa xanthone memperlihatkan bahwa xanthone bersifat antimikro terhadap methicillin-resistant staphylococcus aureus (MRSA), yaitu bakteri yang telah kebal terhadap obat antibiotic yang dapat menyebabkan infeksi parah kandungan mangostin garcione B pada manggis mampu menghambat pertumbuhan bakteri Mycobacterium tuberculosis. Selain itu, xanthone dari kulit manggis dapat mematikan bakteri Salmonella enteritidis yang sering menyebabkan penyakit melalui makanan (Suksamran, 2003).

\section{KESIMPULAN DAN SARAN}

Daun manggis ternyata bisa dijadikan camilan berupa kerupuk daun manggis yang bergizi tinggi dan enak karena di proses khusus. Diolah dengan sedemikian rupa untuk menghasilkan rasa yang pas di lidah para penikmat kerupuk. Olahan daun manggis sendiri masih sangat jarang di Indonesia, mungkin kebanyakan orang berfikir yang dapat diolah hanyalah buah manggis dan kulit buah buah manggis. Kerupuk herbal daun manggis merupakan nama produk kami, merupakan satu inovasi manfaat daun manggis bagi kesehatan yang dikemas menjadi makanan yang di sukai oleh semua kalangan. Pengolahan kerupuk daun manggis juga diharapkan agar produksi daun manggis ini akan terus berlanjut dan bermanfaat bagi kami untuk menciptakan peluang usaha bisnis kerupuk herbal daun manggis yang sangat bermanfaat bagi kesehatan, serta melatih kewirausahan pelajar.

\section{DAFTAR PUSTAKA}

Burger I., Burger B, V., Albrecht C.F., Spicies H.S.C., \& Sandor P. (1998). Samponin triterpenoid dari Bacium gradivlona Var. Obovatum Fitokimia, Volume 49. Hlm. 2087-2089

Deman, JM. (1997). Kimia Makanan. Terjemahan Kosasih Patdmawinata. Bandung: ITB.

Harborne, J.B. (1987). Metode Fitokimia Penuntun Cara Moderen Menganalisis tumbuhan, Diterjemahkan oleh Kosasih Padmawinata dan Imam Sudiro, Edisi I, 9-10, ITB. Bandung.

Hendrawati, A.R.S. (2009). UJI Toksisitas Akut Eksrak Etanol Daun Kemangi(Ocimum sanctum Linn.) Terhadap Artemia salina Leach dengan Metode Brin Shrimp Lethalyt Tes( BSLT). Skripsi. Fakultas Kedokteran Universitas Dipenogoro.

Nurchasanah. (2013). Khasiat Sakti Manggis Tumpas Berbagai Penyakit. Jakarta. Dunia Sehat.

Paramawati, Raffi. (2010). Dahsyatnya Manggis unhtuk Menumpas Penyakit. Jakarta: PT Agro Media Pustaka. 
Prihatman, K. (2000). Manggis (Garcinia manggostana L), Kantor Deputi Menegristek Bidang Pendayagunaan dan pemayarakatan Ilmu Pengetahuan danTeknologi BPP Teknologi, Jakarta.

Putra, I Nengah Kencana. (2010). Aktifitas Antibakteri Ekstrak Kulit Manggis (Garcinia mangostana L) Serta Kandungan Senyawa Aktifnya.J.Teknol. dan Indusri Pangan, Vol. XXI, No.1.

Robinson, T. (1995). Kandungan Organik Tumbuhan Tinggi, Edisi VI, Hal 191-216, Diterjemahkan oleh Kosasih Patmawinata. ITB: Bandung.

Shahidi, F \& Naczk, M. (1995). Foods Phenolics. Di dalam Disertasi Parhusib, A.J.N. Kajian Mekanisme Antibakteri dari Ekstrak Andaliman (Zanthxylum acanthopodium DC) terhadap Bakteri pathogen. Disertasi Pascasarjana, Institusi Pertanian Bogor.

Shahidi, F. (1997). Natural Antiokidant Chemistry, Health Effect and Application. AOCTS Press, IIIionis.

Suksamrarn, S., Suwannapoch, N., phakhodee, W., Thanuhiranlert, J., Ratananukul, P., Chimnoi, N., \& Suksamran, A. (2003). Antimycobacterial Activity of Prenylated Xanthones From the Fruit of Garcinia mangostana, Chem. Phem. Bull. 51 (7), 857859 (Gentianaceae), Drukkerij Elinkwijk bv, Utrecht, pp 109-114. 